\title{
Geographic variation in the trophic ecology of an avian rocky shore predator, the African black oystercatcher, along the southern African coastline
}

\author{
Sophie A. Kohler ${ }^{1,2, *}$, Maëlle Connan ${ }^{2}$, Jaclyn M. Hill ${ }^{2}$, Cécile Mablouké ${ }^{1}$, \\ Bo Bonnevie $^{3}$, Katrin Ludynia ${ }^{4}$, Jessica Kemper ${ }^{5}$, Johan Huisamen ${ }^{6}$, \\ Leslie G. Underhill ${ }^{4}$, Yves Cherel ${ }^{7}$, Christopher D. McQuaid ${ }^{2}$, Sébastien Jaquemet ${ }^{1}$ \\ ${ }^{1}$ Université de La Réunion, Laboratoire ECOMAR, 97400 Saint Denis, La Réunion, France \\ ${ }^{2}$ Department of Zoology and Entomology, and ${ }^{3}$ Information Technology Division, Rhodes University, Grahamstown 6140, \\ South Africa \\ ${ }^{4}$ Animal Demography Unit, Department of Zoology, University of Cape Town, Rondebosch 7701, South Africa \\ ${ }^{5}$ African Penguin Conservation Project, Lüderitz 9000, Namibia \\ ${ }^{6}$ CapeNature, Garden Route, George 6530, South Africa \\ ${ }^{7}$ Centre d'Etudes Biologiques de Chizé, UPR 1934 du CNRS, 79360 Villiers-en-Bois, France
}

\begin{abstract}
The reflection of baseline isotopic signals along marine food chains up to higher trophic levels has been widely used in the study of oceanic top predators but rarely for intertidal predators. We investigated variation in the $\delta^{13} \mathrm{C}$ and $\delta^{15} \mathrm{~N}$ ratios of a sedentary, rocky shore predator, the African black oystercatcher Haematopus moquini, over $2000 \mathrm{~km}$ of the southern African coastline, which is characterized by strong biogeographic patterns in primary productivity and intertidal communities. Blood and feathers from breeding adults and chicks and muscle tissues from primary prey items (mussels and limpets) were sampled between southern Namibia and the southeast coast of South Africa. ${ }^{15} \mathrm{~N}$ enrichment was observed between the southeast and west coasts in oystercatcher tissues and their prey, mirroring an isotope shift between the oligotrophic Agulhas Current on the east coast and the eutrophic Benguela upwelling system on the west coast. Oystercatcher blood showed $\delta^{13} \mathrm{C}$ values that varied between those of the carbon-depleted mussels and the carbon-enriched limpets along the coastline, which reflected changes in the proportion of grazers and filter feeders in the oystercatcher diet across the sampling range. The geographic shift in diet, dominated by mussels on the west coast and composed of mixed proportions of mussels and limpets on the southeast coasts, strongly reflected regionally high abundances of the invasive Mediterranean mussel Mytilus galloprovincialis. Finally, isotope signatures of blood and feathers displayed a strong correlation throughout the study area, indicating seasonal stability in environmental conditions and feeding habits of the adults. There were, however, local discrepancies on the south coast that indicated movement of adults occurred outside the breeding season possibly in response to a lower abundance of food in this region. Overall, the results indicate that the influence of regional oceanic conditions on the base of the food web can penetrate to the predator level, but that local effects can be incorporated within this pattern.
\end{abstract}

KEY WORDS: $\delta^{13} \mathrm{C} \cdot \delta^{15} \mathrm{~N} \cdot$ Shorebirds $\cdot$ Biogeography $\cdot$ Haematopus moquini $\cdot$ Mussels $\cdot$ Limpets Stable isotope mixing model

\section{INTRODUCTION}

Spatial distributions of carbon and nitrogen stable isotopes at the base of marine food webs are affected by oceanic variables such as sea surface temperature and $\mathrm{CO}_{2}$ concentration (Rau et al. 1982, Goericke \& Fry
1994), biochemical processes and the composition of primary producers (Saino \& Hattori 1980). This baseline signal is then transmitted along the food chain in a predictable manner and is ultimately reflected in organisms at higher trophic levels (Cherel \& Hobson 2007). This effect has been widely used to investigate 
spatial and temporal aspects of the feeding ecology of oceanic predators (Burton \& Koch 1999, Quillfeldt et al. 2005, Cherel \& Hobson 2007), but rarely used in largescale studies involving higher trophic level organisms of intertidal ecosystems (but see Atkinson et al. 2005). $\delta^{13} \mathrm{C}$ has been particularly exploited at the lower trophic levels to distinguish between the 2 main potential sources of carbon in intertidal habitats: nearshore benthic and offshore pelagic primary production (Fry \& Sherr 1984, France 1995, Post 2002). Recently, based on the ${ }^{13} \mathrm{C}$ and ${ }^{15} \mathrm{~N}$ signatures of rocky shore, primary producers and consumers, Hill et al. (2006) and Hill \& McQuaid (2008) described 4 isotopic regions and continuous gradients of $\delta^{13} \mathrm{C}$ and $\delta^{15} \mathrm{~N}$ ratios between the Mozambican and Namibian coasts (Fig. 1). These reflected variations in coastal hydrographic features along the coastline and the shift between oligotrophic and eutrophic conditions set, respectively, by the Agulhas Current that brings warm waters from the Mozambique Channel along the east and south coasts (Lutjeharms 2004) and the nutrient-rich Benguela upwelling system that flows northwards along the west coast (Shannon 1985).

The trophic structure of southern African rocky shores has also been profoundly influenced by the accidental introduction of the Mediterranean mussel
Mytilus galloprovincialis to the west coast of South Africa in the 1970s (Grant \& Cherry 1985). The arrival of this invasive species has caused major changes in the structure and functioning of intertidal communities on these rocky shores (Robinson et al. 2007). Because of its higher physiological performances, dispersal rates and ability to colonize free space (Branch \& Steffani 2004, Erlandsson et al. 2006), this invasive species has replaced the indigenous mussels Aulocomya ater and Choromytilus meridionalis as the dominant mussel on the mid and low shores on the west coast (Robinson et al. 2007). Moreover M. galloprovincialis outcompetes adult limpets (Scutellastra argenvillei and S. granularis) for primary space on exposed rocky shores on the west coast (Hockey \& van Erkom Schurink 1992, Steffani \& Branch 2003). The Mediterranean mussel was also introduced for aquaculture in Port Elizabeth on the south coast in 1988 (McQuaid \& Phillips 2000). The distributions of the indigenous Perna perna and $M$. galloprovincialis now overlap in this region. But where they co-occur they exhibit partial spatial segregation, and $M$. galloprovincialis dominates the upper mussel zone, $P$. perna the lower zone and a mix of the 2 species occurs in the mid-mussel zone (Bownes \& McQuaid 2006). At the start of the 21st century, M. galloprovincialis occurred along $2000 \mathrm{~km}$ of shoreline from

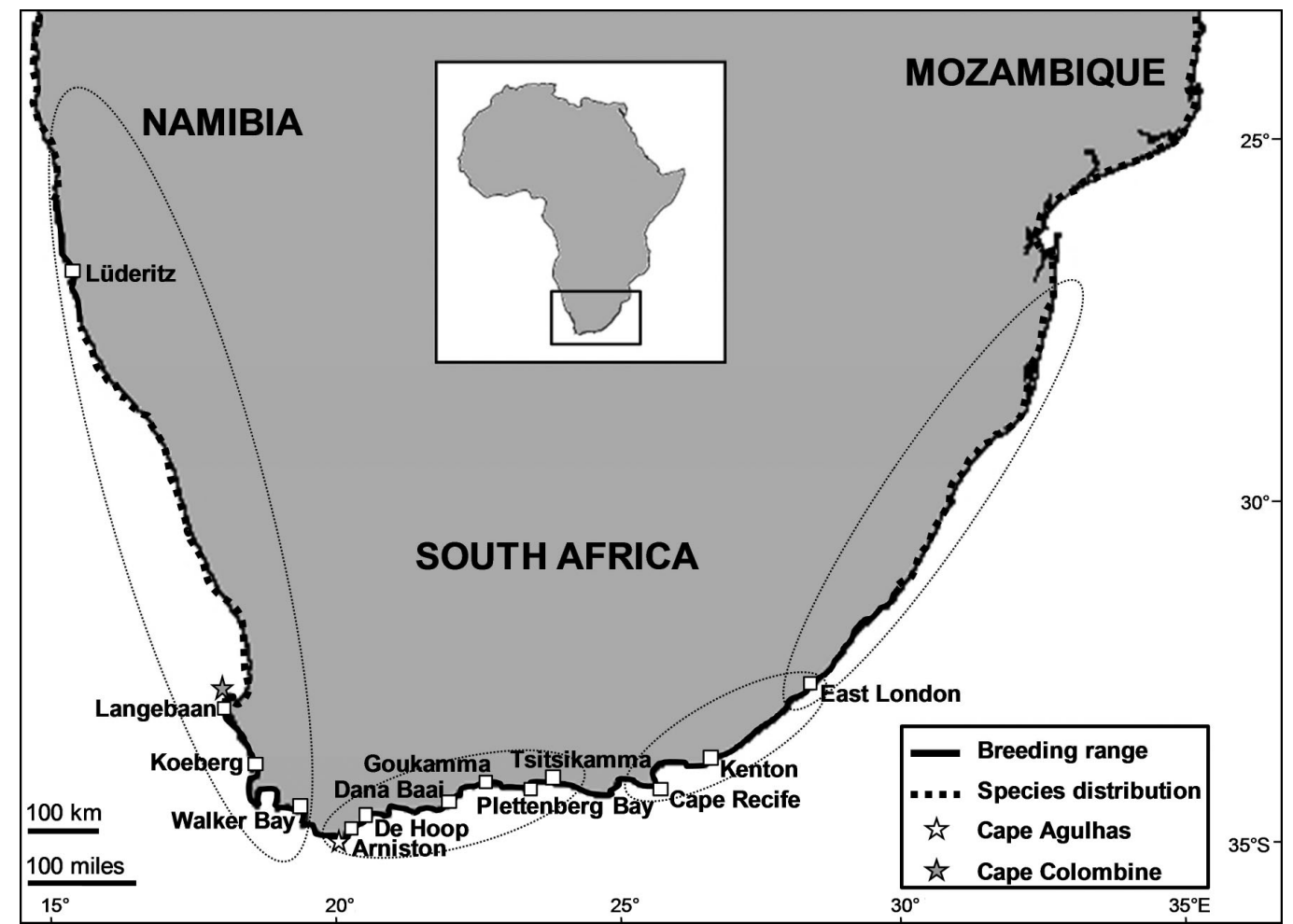

Fig. 1. Haematopus moquini. Breeding sites where African black oystercatchers and prey were sampled (open squares). Isotopic regions described in Hill et al. (2006) and Hill \& McQuaid (2008) are delineated by dotted ellipses. Inset shows location of study area in southern Africa 
Namibia to South Africa and dominated intertidal biomass on the west coast (Robinson et al. 2005).

Although the arrival of Mytilus galloprovincialis on the southern African coasts had mostly negative effects for the rocky shore communities, it has benefited a near-threatened endemic shorebird species, the African black oystercatcher Haematopus moquini (ABO). Since the 1980s, the reproductive output of ABOs has increased in response to a combination of conservation measures and enhanced mussel biomass owing to the invasive species on the west coast (Hockey \& Van Erkom Schurink 1992, Hockey 1997, Williams et al. 2004, Tjørve \& Underhill 2006). As a consequence, in the past $30 \mathrm{yr}$, the overall population has increased from 4800 (Hockey 1983) to 6000 birds (Hockey et al. 2005), which might be an underestimation of the present population size. The breeding range of this shorebird has also expanded eastwards (Vernon 2004, Brown \& Hockey 2007). This seems to reflect a spillover effect, in which vagrant individuals from the burgeoning west coast populations are spreading farther east (Vernon 2004), rather than a direct consequence of the eastward spread of M. galloprovincialis, as this mussel is present at only low abundances at most sites on the southeast coast (von der Meden et al. 2008). The breeding range of ABOs now extends from the Lüderitz region of southern Namibia to the southeast coast of South Africa, with a gap between the Lüderitz region and Cape Columbine on the west coast (Hockey et al. 2005; our Fig. 1). ABOs are nonmigratory and are territorial during the breeding season, which is from October to March in South Africa (Hockey et al. 2005) and from January to June in Namibia (J. Kemper pers. obs.). They depend exclusively on intertidal invertebrates, mostly mussels and limpets, for their food (Hockey \& Underhill 1984). This set of features makes them excellent biological model organisms with which to study the influence of physical processes and biological perturbation on intertidal communities. In particular, it makes them ideal for the study of how conditions at the base of the intertidal food web are transmitted to higher trophic levels under different environmental conditions.

We investigated the trophic ecology of this rocky shore predator across the full extent of its breeding range, relating this to spatial changes in the local assemblages of prey species in its habitat and to larger oceanic processes. Analysis of stable carbon and nitrogen isotope signatures allowed us to examine the balance between biogeographic and local effects and to test whether the $\mathrm{ABO}$ responded more strongly to large-scale oceanic characteristics, conforming to previously defined isotopic provinces (Hill et al. 2006), or whether local physical and biological conditions have a more powerful influence.

\section{MATERIALS AND METHODS}

Sample collection. Breeding oystercatchers and their chicks were sampled during 3 consecutive breeding seasons (from December 2007 to April 2010), at 13 sites from Lüderitz $\left(26^{\circ} 38.8^{\prime} \mathrm{S}, 15^{\circ} 9.2^{\prime} \mathrm{E}\right)$ on the south coast of Namibia to East London (33 $3.2^{\prime} \mathrm{S}, 27^{\circ} 52.4^{\prime} \mathrm{E}$ ) on the southeast coast of South Africa (Fig. 1). Adult birds were caught at the nest during incubation with a walk-in trap and chicks (10 d to 7 wk old) were caught by hand. Blood samples $(0.5 \mathrm{ml})$ were taken from the tarsal vein of both the adults and chicks and subsequently preserved in $70 \%$ ethanol. Body feathers (5 to 8) were collected from each adult and from large chicks (5 to 7 wk old). All captured birds were tagged with a uniquely engraved ring (SAFRING) before their release. In addition, potential prey species were collected at each site for stable isotope analysis. Collection focused on mussel and limpet species as they are known to form the bulk of oystercatcher diet on rocky shores (Hockey \& Underhill 1984, Hockey \& Van Erkom Schurink 1992, Kohler et al. 2009). Five similarly sized specimens of each species were collected at each breeding area and stored at $-20^{\circ} \mathrm{C}$ until further processing. Across the whole study area, the prey species collected comprised the mussels Perna perna, Mytilus galloprovincialis, Choromytilus meridionalis, Aulocomya ater and the limpets Cymbula oculus, Scutellastra argenvillei, S. cochlear, S. granatina, S. granularis and $S$. longicosta. Not all of these species occur throughout the study region, which comprises 2 major biogeographic provinces. In addition, the Benguela system and the Agulhas Current give rise to broad geographic differences in nutrient concentration, intertidal primary production and ultimately species assemblages and biomass along the coastline (Emanuel et al. 1992, Bustamante \& Branch 1996). Intertidal biomass is greater on the west coast than on the south and east coasts, which are in turn characterized by higher species richness. Local hydrography plays an important role in the ecosystem dynamics of rocky shore communities (Menge et al. 2003). On the South African coastline in particular, temporal variability in hydrographic processes may profoundly affect the composition and distribution of nearshore suspended particulate matter (SPM) and subsequently its ${ }^{13} \mathrm{C}$ signatures (Hill et al. 2008). Consequently, prey species and oystercatchers at a given site were sampled during the same breeding season as far as possible to limit temporal effects on isotope signatures. However, in order to cover the entire study area $(\sim 2000 \mathrm{~km})$ and sample sufficient numbers of birds, it was logistically necessary to sample over 3 breeding seasons (see Table 1).

Sample preparation and isotope analysis. Whole blood has a rapid turnover rate and for birds gives 
information on the diet integrated over a few weeks before sampling (Hobson \& Clark 1992a, Bearhop et al. 2002). Isotopic signatures of blood collected in summer were therefore used as a proxy for the diet of adults and chicks during the breeding season. Adult feathers are produced during moult and remain metabolically inert once fully grown (Mizutani et al. 1990). No published data exist on the moult of ABOs; however, it is believed that this takes place from March to September, i.e. during the nonbreeding season (L. G. Underhill pers. obs.). Moreover, other shorebirds (Klaassen et al. 2001, Atkinson et al. 2005) and oystercatcher species (Dare \& Mercer 1974, Hulscher 1977) are known to moult during the wintering/nonbreeding season. Therefore, we assume that the isotopic composition of adult body feathers reflects their diet during the nonbreeding season (Jaeger et al. 2009). Different tissues have different protein turnover rates and routings. Consequently, ${ }^{13} \mathrm{C}$ and ${ }^{15} \mathrm{~N}$ signatures vary from one tissue to the other and this must be taken into consideration when comparing isotopic signatures of different tissues (Tieszen et al. 1983, Vanderklift \& Ponsard 2003, Cherel et al. 2005). In large chicks, the isotopic composition of blood and newly grown feathers is representative of the diet integrated over about the same period of time. For this reason, in addition to blood, body feathers were also collected from 20 large chicks to estimate differences in diet-tissue isotopic discrimination between blood and feathers. Prey species were analysed by means of their muscle tissues because of their slow isotopic turnover rate and because they are unlikely to be affected by short-term environmental fluctuations (Gorokhova \& Hansson 1999). Consequently, the adductor muscle of mussels and the foot muscle of limpets were analysed for their isotopic composition to provide an isotopic signal integrated over a period of months (Hill \& McQuaid 2009). A limpet's foot represents the majority of their body mass, while the adductor tissue of a mussel is only a small part of the whole animal. However, adductor tissue and whole mussels only differ by a ${ }^{13} \mathrm{C}$-enrichment of $0.5 \%$ in their stable isotope signature (S. A. Kohler et al. unpubl. data). Therefore, conclusions regarding geographic changes in the stable isotope signatures of benthic invertebrates and outputs of stable isotope mixing models (see below) are likely to be unaltered (Lefebvre et al. 2009). Blood samples were dried $\left(60^{\circ} \mathrm{C}, 24 \mathrm{~h}\right)$ and reduced to a homogenous powder. Pooled body feathers from a given individual were cleaned of surface contaminants and lipids by immersion in a 2:1 chloroform:methanol solution, placed in an ultrasound bath for $2 \mathrm{~min}$ and then rinsed with distilled water and dried $\left(60^{\circ} \mathrm{C}, 24 \mathrm{~h}\right)$. Muscle tissues of mussels and limpets were cut out, rinsed thoroughly with distilled water and dried $\left(60^{\circ} \mathrm{C}, 24 \mathrm{~h}\right)$. All dried samples were then reduced to a homogenous powder. Relative isotope abundance of carbon $\left({ }^{13} \mathrm{C} /{ }^{12} \mathrm{C}\right)$ and nitrogen $\left({ }^{15} \mathrm{~N} /{ }^{14} \mathrm{~N}\right)$ were determined from $\sim 1 \mathrm{mg}$ subsamples of the homogenous powder in a continuous flow isotope ratio mass spectrometer (IRMS) after sample combustion in an online Carlo-Erba preparation unit. Results are expressed relative to the international standards of Pee Dee belemnite for carbon and atmospheric $\mathrm{N}_{2}$ (air) for nitrogen. The standard notation is $\delta X\left[\left(R_{\text {sample }} / R_{\text {standard }}\right)-1\right] \times 1000(\%)$, where $X$ is the element considered and $R$ is the ratio of heavy to light isotope. Precision of replicate determinations was $<0.10 \%$ for carbon and $<0.13 \%$ o for nitrogen. All samples were analyzed at the Stable Light Isotope Unit of the University of Cape Town, South Africa.

Trophic enrichment factors (TEF). Isotopic enrichment between diet and consumer tissues results from isotopic fractionation during assimilation, protein synthesis and excretion (Ponsard \& Averbuch 1999). The estimation of prey contribution using stable isotope mixing models requires knowledge of an estimated TEF. TEFs can vary among species or taxa and have been widely investigated in seabirds (Hobson \& Clark 1992b, Bearhop et al. 2002, Cherel et al. 2005), but to our knowledge in only one shorebird species, the dunlin Calidris alpina pacifica (Evans Ogden et al. 2004). TEFs found between diet and whole blood of dunlins were $+1.3 \%$ for $\delta^{13} \mathrm{C}$ and $+2.9 \%$ for $\delta^{15} \mathrm{~N}$. As $\delta^{13} \mathrm{C}$ is the major discriminant between mussels and limpets (Kohler et al. 2009), the TEF for $\delta^{13} \mathrm{C}$ needs to be as reliable as possible (Dalerum \& Angerbjörn 2005). Therefore, we estimated the TEF for $\delta^{13} \mathrm{C}$ and $\delta^{15} \mathrm{~N}$ by comparing the isotopic compositions of oystercatcher blood and their prey at 4 sites where only one type of prey (either mussels or limpets) was available and where extensive feeding observations confirmed that this unique prey was the main food ingested by oystercatchers (S. A. Kohler unpubl. data). Results showed mean $( \pm \mathrm{SD})$ TEFs of $+0.2 \%$ o $( \pm 0.4 \%)$ for $\delta^{13} \mathrm{C}$ and $+2.7 \%$ o $\left( \pm 0.4 \%\right.$ o for $\delta^{15} \mathrm{~N}$, which are within the range of values found for other marine birds (Hobson \& Clark 1992b, Bearhop et al. 2002, Cherel et al. 2005), but the TEF for $\delta^{13} \mathrm{C}$ was noticeably different from that for dunlins (Evans Ogden et al. 2004).

Prey contributions. To investigate variations in the relative contribution of mussels and limpets to the diet of oystercatchers along the coastline, we used the Bayesian stable isotope mixing model SIAR. The SIAR package (Parnell et al. 2010, available at http://cran.rproject.org/web/packages/siar/index.html), running on the statistical software R (R Development Core Team 2008), allows the incorporation of standard deviations of mean sources and consumers signatures as well as uncertainty regarding diet-consumer discrimi- 
Table 1. Haematopus moquini. Carbon and nitrogen stable isotope values of blood (adults and chicks) and body feathers (adults only) of African black oystercatchers. Values are mean $\pm \mathrm{SD}$

\begin{tabular}{|c|c|c|c|c|c|c|c|c|}
\hline \multirow[t]{2}{*}{ Sites } & \multicolumn{2}{|c|}{ Blood (adults + chicks) } & \multicolumn{2}{|c|}{ Feathers (adults only) } & \multicolumn{3}{|c|}{$\longrightarrow \mathrm{N}$} & \multirow{2}{*}{$\begin{array}{l}\text { Sampling } \\
\text { seasons }^{\mathrm{a}}\end{array}$} \\
\hline & $\delta^{13} \mathrm{C}(\%)$ & $\delta^{15} \mathrm{~N}(\%)$ & $\delta^{13} \mathrm{C}(\%)$ & $\delta^{15} \mathrm{~N}(\%)$ & Adults & Chicks & Total & \\
\hline Lüderitz & $-15.2 \pm 0.5$ & $12.4 \pm 0.7$ & $-13.8 \pm 0.2$ & $13.6 \pm 0.9$ & 3 & 1 & 4 & 2010 \\
\hline Langebaan & $-14.9 \pm 0.2$ & $13.2 \pm 0.4$ & $-14.5 \pm 1.0$ & $14.9 \pm 0.3$ & 4 & 2 & 6 & 2009 \\
\hline Koeberg & $-14.6 \pm 0.6$ & $11.6 \pm 0.3$ & $-13.8 \pm 0.4$ & $13.2 \pm 0.1$ & 4 & 4 & 8 & 2008 and 2009 \\
\hline Walker Bay & $-14.4 \pm 0.1$ & $11.6 \pm 0.2$ & -13.5 & 12.8 & 1 & 3 & 4 & 2009 and 2010 \\
\hline Arniston & $-15.6 \pm 0.3$ & $11.3 \pm 03$ & $-14.9 \pm 0.3$ & $12.8 \pm 0.2$ & 6 & 1 & 7 & 2009 \\
\hline De Hoop & $-14.8 \pm 0.6$ & $11.8 \pm 0.4$ & $-14.9 \pm 0.3$ & $12.8 \pm 0.2$ & 5 & 7 & 12 & 2009 \\
\hline Dana Baai & $-15.9 \pm 0.5$ & $10.5 \pm 0.4$ & $-15.8 \pm 0.3$ & $13.8 \pm 0.1$ & 2 & 8 & 10 & 2009 \\
\hline Goukamma & $-15.5 \pm 0.5$ & $11.4 \pm 0.4$ & $-15.0 \pm 0.4$ & $13.3 \pm 0.3$ & 8 & 9 & 17 & 2009 \\
\hline Plettenberg Bay & $-15.3 \pm 0.8$ & $11.0 \pm 0.6$ & $-14.9 \pm 0.6$ & $12.8 \pm 0.2$ & 5 & 2 & 7 & 2009 \\
\hline Tsitsikamma & $-13.2 \pm 0.0$ & $11.3 \pm 0.2$ & -12.3 & 12.8 & 1 & 1 & 2 & 2010 \\
\hline Cape Recife & $-13.6 \pm 0.8$ & $11.9 \pm 0.4$ & $-13.1 \pm 1.0$ & $13.5 \pm 0.4$ & 12 & 6 & 18 & 2008 and 2009 \\
\hline Kenton & $-14.4 \pm 0.9$ & $11.2 \pm 0.4$ & $-13.7 \pm 0.9$ & $12.7 \pm 0.4$ & 10 & 7 & 17 & 2008 and 2009 \\
\hline East London & $-13.0 \pm 1.4$ & $10.5 \pm 0.6$ & $-11.6 \pm 1.6$ & $11.4 \pm 0.5$ & 11 & 13 & 24 & 2008 \\
\hline
\end{tabular}

nation. We used mean $( \pm \mathrm{SD})$ signatures of oystercatcher blood (Table 1) and prey (Table 2) and the TEFs given above to calculate prey contributions at each location. No limpets were present on the feeding grounds at De Hoop, Dana Baai and Goukamma, but for reasons of comparison, limpet signatures from nearby areas (less than $50 \mathrm{~km}$ away) were included to run the model for these sites (see footnotes in Table 2). With the SIAR outputs, an a posteriori aggregation (Phillips et al. 2005) was carried out to pool results for limpet species on one side and for mussel species on the other side.

Statistical analyses. All statistical analyses were performed with R Statistical software (R Development Core Team 2008). When data sets did not meet the assumptions of normal distribution (Shapiro-Wilks test, $\mathrm{p}<0.05$ ) or homoscedasticity (Bartlett's test, $\mathrm{p}<0.05$ ), nonparametric procedures were used. Although the purpose of this study was not to investigate differences between individuals at a local scale, we tested local differences between age groups to see whether adults and chicks from the same site could be considered as a homogenous local population. A 2-way ANOVA $(\alpha=$ $0.05)$ was performed with sites $(n=13)$ and age (chicks or adults) as factors and $\delta^{13} \mathrm{C}$ or $\delta^{15} \mathrm{~N}$ as response variables for each site. There was a significant effect of site on individuals for both $\delta^{13} \mathrm{C}\left(F_{12,123}=13.66, \mathrm{p}<0.01\right)$ and $\delta^{15} \mathrm{~N}\left(F_{12,123}=24.57, \mathrm{p}<0.01\right)$ values. Chicks were slightly but significantly depleted by $0.4 \%$ o in ${ }^{13} \mathrm{C}$ $\left(F_{1,122}=5.85, \mathrm{p}=0.02\right)$ and by $-0.3 \%$ in ${ }^{15} \mathrm{~N}\left(F_{1,122}=30\right.$, $\mathrm{p}<0.01)$ compared with adults. There was no interaction between site and age $\left(\delta^{13} \mathrm{C}: F_{11,122}=1.27, \mathrm{p}=0.25\right.$; $\left.\delta^{15} \mathrm{~N}: F_{11,122}=1.46, \mathrm{p}=0.15\right)$ and adult and chick isotope signatures showed very strong correlations $\left(\delta^{13} \mathrm{C}\right.$ :
$\mathrm{R}^{2}{ }_{\text {adults-chicks }}=0.85, \mathrm{p}<0.01 ; \delta^{15} \mathrm{~N}: \mathrm{R}^{2}$ adults-chicks $=0.93, \mathrm{p}<$ $0.01)$, meaning that adult and chick signatures covaried along the coastline. Geographic variations of chick and adult blood signatures are represented separately and correlation tests were performed for each age group. We pooled chicks and adults for the estimation of the contributions of limpet and mussel to the diet of ABOs along the coastline (see 'Prey contributions' in 'Materials and methods') because the SIAR model incorporates individual variability in the output. Geographic grouping of $\delta^{13} \mathrm{C}$ and $\delta^{15} \mathrm{~N}$ values of adult tissues were analyzed with a K-means cluster analysis, and then subsequently tested with a discriminant function analysis (DFA). We also tested whether the presence of Mytilus galloprovincialis and/or limpets on the feeding grounds had an effect on the overall contribution of mussels (estimated from SIAR) to the ABO diet, using a 2-way ANOVA $(\alpha=0.05)$.

\section{RESULTS}

\section{Benthic invertebrates: isotopic variation among sites, trophic groups and species}

Across the study region, individual carbon isotope signatures for mussels ranged from $-18.9 \%$ (Choromytilus meridonalis, Lüderitz) to $-13.7 \%$ (Mytilus galloprovincialis, Tsitsikamma) and for limpets from $-16.1 \%$ (Scutellastra granatina, Lüderitz) to $-5.3 \%$ o (S. longicosta, East London). Filter feeders and grazers were separated by their $\delta^{13} \mathrm{C}$ values with mussels being depleted in carbon at all sites compared with limpets (Fig. 2). Differences in their carbon isotope signatures, how- 


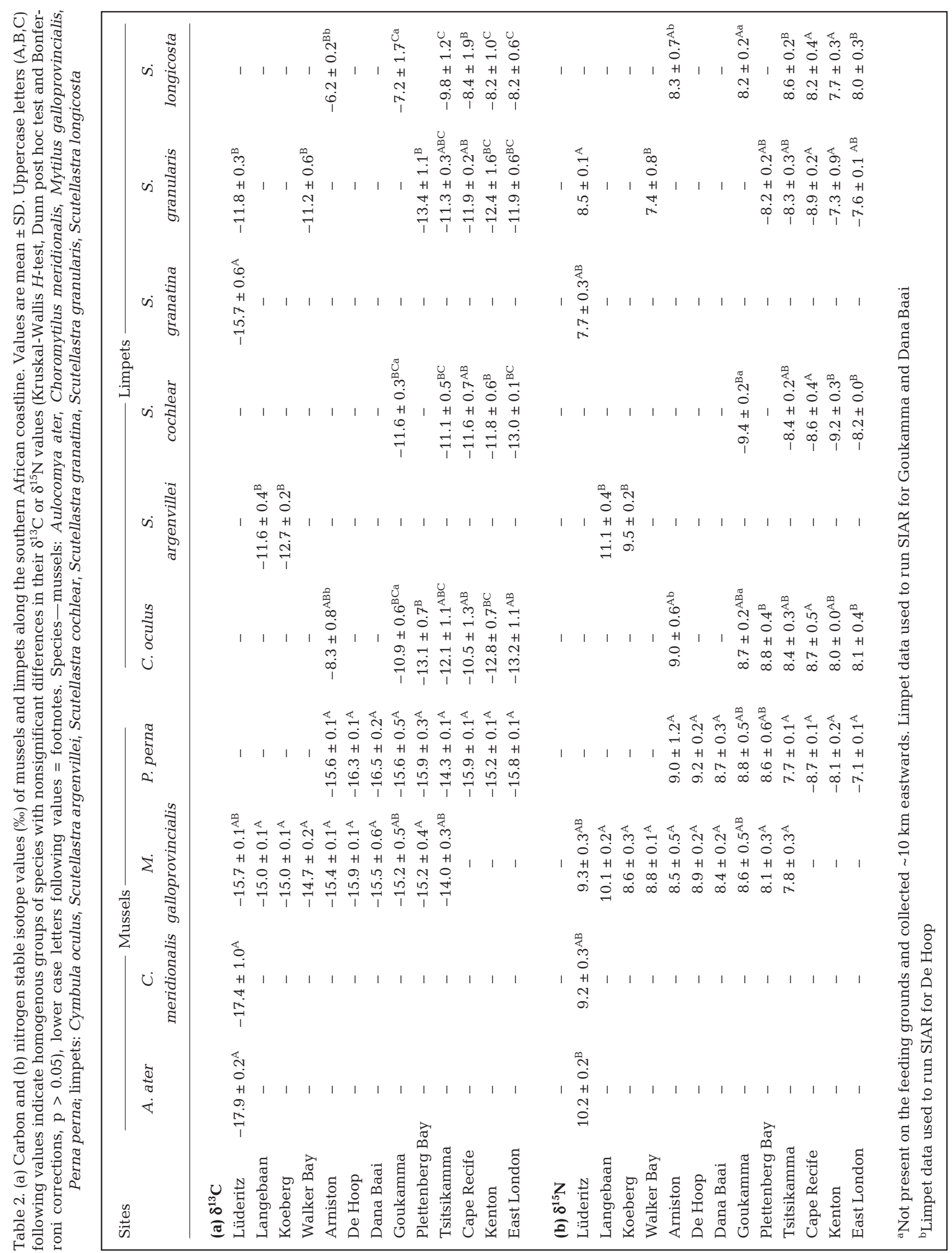




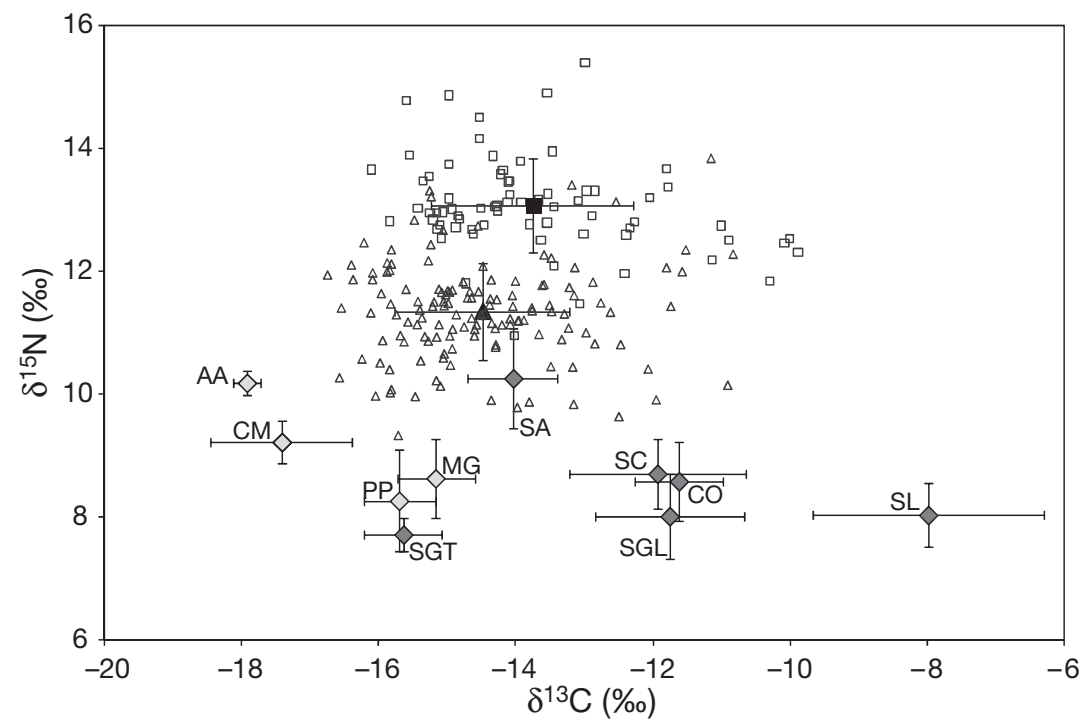

Fig. 2. Stable carbon and nitrogen isotope ratios (\%) of African black oystercatchers, mussels and limpets across the sampling area. Individual isotope ratios of blood $(\Delta$, adults and chicks, $n=136)$ and feathers $(\square$, adults, $n=72)$. Mean $\pm S D$ isotopic values of blood ( $\boldsymbol{\Lambda}$, adults and chicks) and feathers ( $\boldsymbol{\square}$, adults). Mean \pm $\mathrm{SD}$ isotopic values of mussels $(\diamond, \mathrm{AA}$ : Aucolomya ater; CM: Choromytilus meridionalis; MG: Mytilus galloprovincialis; PP: Perna perna) and limpets $(\diamond, \mathrm{CO}$ Cymbula oculus; SA: Scutellastra argenvillei; SC: S. cochlear; SGT: S. granatina; SGL: S. granularis; SL: S. longicosta)

ever, were not always significant (Table 2) and in Lüderitz, M. galloprovincialis and the limpet $S$. granatina both had a mean $\delta^{13} \mathrm{C}$ ratio of $-15.7 \%$. Overall no consistent separation in the $\delta^{15} \mathrm{~N}$ values of mussels and limpets was observed (Table 2, Fig. 2). However, west of Cape Agulhas (Namibia excluded), the only mussel present, M. galloprovincialis, was significantly depleted in ${ }^{15} \mathrm{~N}$ compared with the dominant limpets, $S$. argenvillei and $S$. granularis (Table 2).

The invasive mussel Mytilus galloprovincialis and the indigenous brown mussel Perna perna co-occurred at 6 locations (Table 2). No significant differences in carbon or nitrogen isotope ratios were recorded between the 2 species at a local scale (Table 2, Fig. 2). In Namibia, M. galloprovincialis was significantly enriched in ${ }^{13} \mathrm{C}$ compared with the indigenous mussels Choromytilus meridionalis and Aulocomya ater (Table 2). When Scutellastra longicosta was present, this limpet was always enriched in ${ }^{13} \mathrm{C}$ compared with other limpets (Table 2, Fig. 2). Overall, the different limpet species had similar $\delta^{15} \mathrm{~N}$ values throughout the sampling area (Table 2).

Muscle $\delta^{13} \mathrm{C}$ values of mussels and limpets did not show any geographic trends along the coastline. The lowest mean ${ }^{13} \mathrm{C}$ signatures for both mussels and limpets were observed in Lüderitz, while the highest signatures for mussels were in Tsitsikamma and for limpets in Arniston, near Cape Agulhas. However, it is worth noting that the mean $\delta^{13} \mathrm{C}$ signatures of limpets presented in Fig. 3a were affected by the presence or absence of Scutellastra longicosta, which was particularly enriched in ${ }^{13} \mathrm{C}$.

Unlike carbon signatures, nitrogen isotope signatures showed a clear geographic pattern. The $\delta^{15} \mathrm{~N}$ values of mussels varied from $9.6 \%$ in Lüderitz (west coast, Namibia) to $7.1 \%$ in East London (southeast) and they displayed a significant depletion (Pearson's correlation test: $\mathrm{R}^{2}$ mussels-longitude $=0.80, \mathrm{p}<$ 0.01 ) from the west to the southeast coast (Fig 3b). Geographic patterns in $\delta^{15} \mathrm{~N}$ signatures of limpets were not as clear and a marginally significant depletion was only observed from Arniston (close to Cape Agulhas) and eastwards (Pearson's correlation test: $\mathrm{R}^{2}$ limpets-longitude $=0.76, \mathrm{p}=0.05$ ). Particularly high ${ }^{15} \mathrm{~N}$ signatures were observed for both mussels and limpets at Langebaan on the west coast compared with neighbouring sites and to a lesser extent, this was also the case on the south coast for Cape Recife compared with Kenton and Tsitsikamma (Fig. 3b). In Walker Bay, limpets displayed depletion in ${ }^{15} \mathrm{~N}$ compared with those sampled at the nearest sites, Koeberg to the west and Arniston to the east (Fig 3b).

\section{African black oystercatchers: geographic and tissue-specific variations in their isotopic signatures}

Altogether, 136 oystercatchers (53\% adults and $47 \%$ chicks) were sampled during this study. Oystercatcher blood showed $\delta^{13} \mathrm{C}$ values (from $-16.7 \%$ in Dana Baai to $-10.8 \%$ in East London) that were intermediate between those of mussels and limpets (Fig. 2). $\delta^{15} \mathrm{~N}$ values ranged from 9.3\% (East London) to 13.8\%o (Langebaan) and on average were enriched by $+2.7 \%$ o $( \pm 0.4)$ compared with benthic invertebrates (Fig. 2). Blood-feather discrimination in adults was $+0.5 \%$ o $( \pm 0.5)$ for $\delta^{13} \mathrm{C}$ and $+1.6 \%$ o $( \pm 0.4)$ for $\delta^{15} \mathrm{~N}(\mathrm{n}=71)$. Mean blood-feather isotopic discrimination of the 20 largest chicks sampled was not strongly different: $+0.9 \%$ o $( \pm 0.3)$ for $\delta^{13} \mathrm{C}$ and $+1.2 \%$ o $( \pm 0.3)$ for $\delta^{15} \mathrm{~N}$.

No significant correlation existed between the geographic variations of $\delta^{13} \mathrm{C}$ values of mussels or limpets and the blood of ABOs (Spearman's rank correlation test, adults: $\mathrm{R}^{2}$ blood-mussels $=0.41, \mathrm{p}=0.16$ and $\mathrm{R}^{2}$ blood-limpets $=0.01, \mathrm{p}=0.98$; chicks: $\mathrm{R}^{2}$ blood-mussels $=0.47$, $\mathrm{p}=0.10$ and $\mathrm{R}_{\text {blood-limpets }}=0.20, \mathrm{p}=0.55$ ), nor did blood display clear geographic patterns in ${ }^{13} \mathrm{C}$ signatures. 

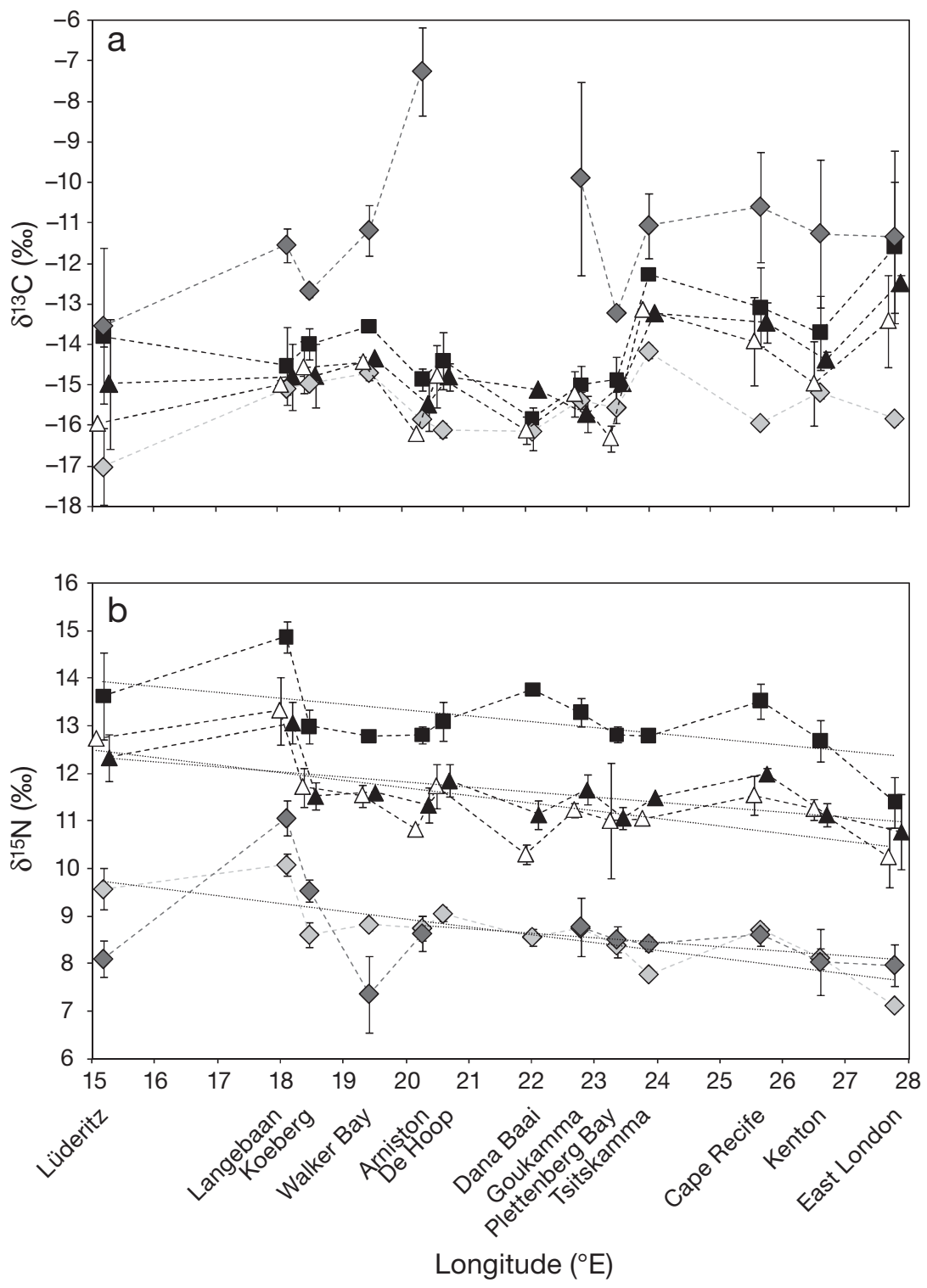

Fig. 3. Stable (a) carbon and (b) nitrogen isotope ratios (\%) of blood ( $\mathbf{\Delta}$ ) and feathers ( $\mathbf{\square})$ of adult African black oystercatchers, blood of chicks $(\Delta)$, mussels $(\diamond)$ and limpets $(\diamond)$ along the coastline. Values are mean \pm SD. Dotted lines indicated significant correlation with longitude. Signatures for adults and chicks are deliberately shifted for more clarity

However, an increase in the ${ }^{13} \mathrm{C}$ signatures in blood was visible between Plettenberg Bay and the more easterly sites. Overall, blood $\delta^{13} \mathrm{C}$ values varied between the mean values of mussels and limpets along the coastline, suggesting that the ${ }^{13} \mathrm{C}$ signatures of ABOs were dependent on the relative consumption of filter feeders or grazers. Carbon isotope signatures for the blood and feathers of adults displayed identical patterns across the $\mathrm{ABO}$ breeding range (Fig. 3a) and showed a strong correlation (Pearson's correlation test: $\mathrm{R}^{2}$ blood-feathers $\left.=0.92, \mathrm{p}<0.01\right)$.
The $\delta^{15} \mathrm{~N}$ variations of $\mathrm{ABO}$ tissues along the coastline showed very similar patterns to mussels (Pearson's correlation test, adults: $\mathrm{R}^{2}$ blood-mussels $=$ $0.86, \mathrm{p}<0.01$; chicks: $\mathrm{R}^{2}$ blood-mussels $=$ $0.85, \mathrm{p}<0.01$ ). Significant depletion was observed from Lüderitz to East London in the blood of adults and chicks (Pearson's correlation test, adults: $\mathrm{R}^{2}$ blood-longitude $=0.61, \mathrm{p}=0.03$; chicks: $\mathrm{R}^{2}$ blood-limpets $\left.=0.69, \mathrm{p}<0.01\right)$ and in adult feathers (Pearson's correlation test: $\mathrm{R}^{2}$ feathers-longitude $=0.57, \mathrm{p}=$ $0.04)$. Blood and feathers of adults displayed very significant correlations along the coastline (Pearson's correlation test: $\mathrm{R}^{2}$ blood-feathers $=0.81, \mathrm{p}<0.01$ ) between Namibia and the southeast coast of South Africa (Fig. 3b).

K-means classifications based on the $\delta^{13} \mathrm{C}$ and $\delta^{15} \mathrm{~N}$ ratios of blood and feathers of adults showed a similar biogeographic pattern between tissues (Fig. 4a,b). Classifications were subsequently confirmed by a DFA with $100 \%$ accuracy. Group A was characterized by enriched ${ }^{13} \mathrm{C}$ signatures in blood (Group A centroids: $\delta^{13} \mathrm{C}=$ $-13.1 \%$, $\delta^{15} \mathrm{~N}=11.4 \%$ ) and grouped 3 of the 4 most eastern sites together (Tsitsikamma being at the eastern limit of the southwest coast) (Fig. 4a). Group B had intermediate ${ }^{13} \mathrm{C}$ signatures and enriched ${ }^{15} \mathrm{~N}$ signatures (Group B centroids: $\delta^{13} \mathrm{C}=-14.7 \%$, $\delta^{15} \mathrm{~N}=11.9 \%$ ) compared with other groups and was composed not only of all the western sites but also Kenton (southeast coast) and De Hoop (southwest coast). Group C was exclusively composed of southwest coast sites and was defined by depleted ${ }^{13} \mathrm{C}$ signatures and ${ }^{15} \mathrm{~N}$ signatures similar to those of Group B (Group C centroids: $\delta^{13} \mathrm{C}=-15.3 \%, \delta^{15} \mathrm{~N}=11.3 \%$ ). Feather classification displayed a similar pattern, with the exception of Cape Recife that fell into Group B with the western sites, De Hoop and Kenton.

\section{Trophic relationships between benthic invertebrates and African black oystercatchers along the coastline}

The relative contributions of mussels and limpets to the diet of ABOs varied greatly across the sampling 


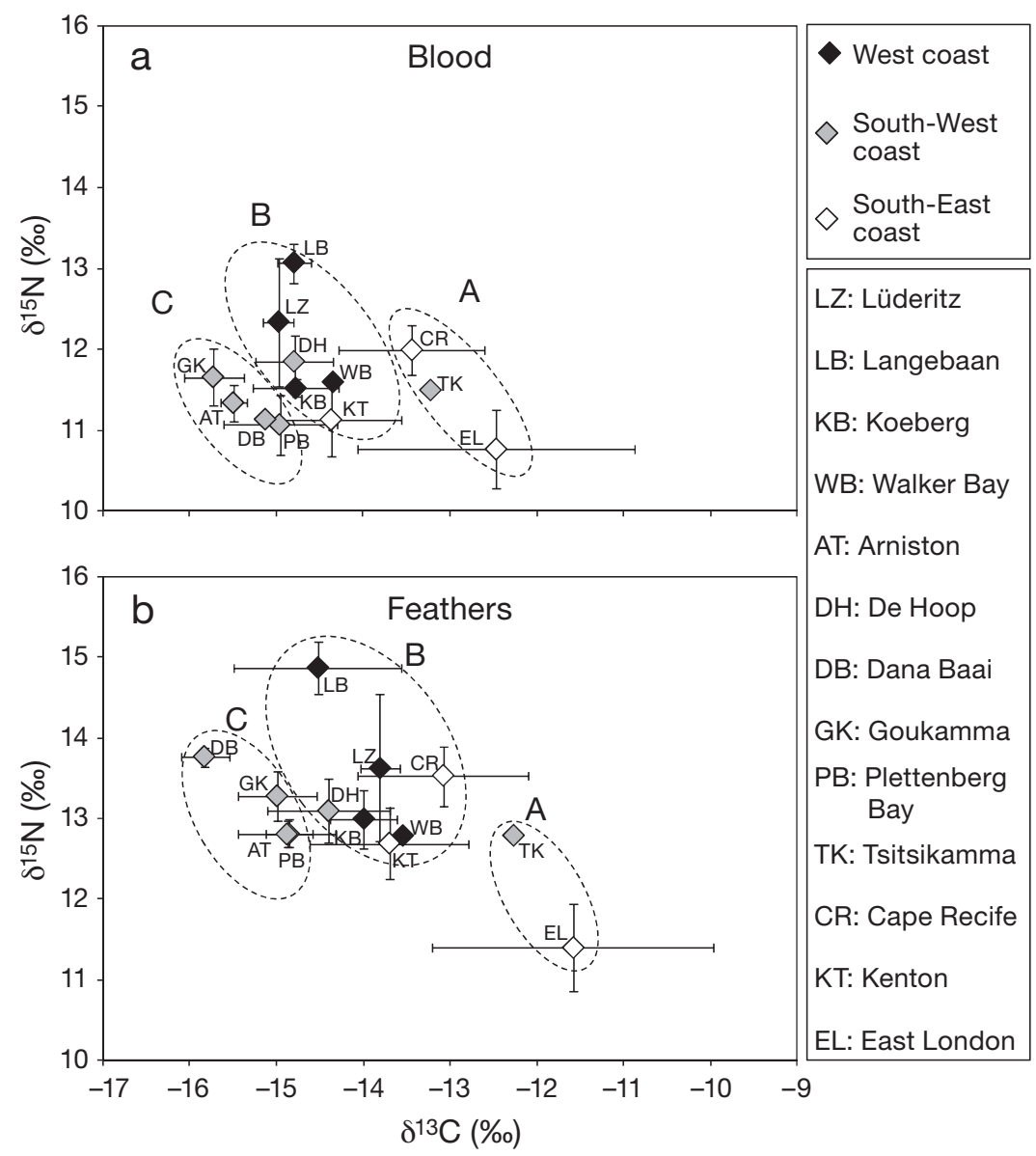

Fig. 4. Haematopus moquini. $\delta^{13} \mathrm{C}$ and $\delta^{15} \mathrm{~N}$ ratios in (a) blood and (b) feathers of adult birds. Dotted circles indicate grouping of sites according to K-means cluster analysis and confirmed by a discriminant function analysis. Shading of diamonds shows the biogeographic regions described by Hill et al. (2006)

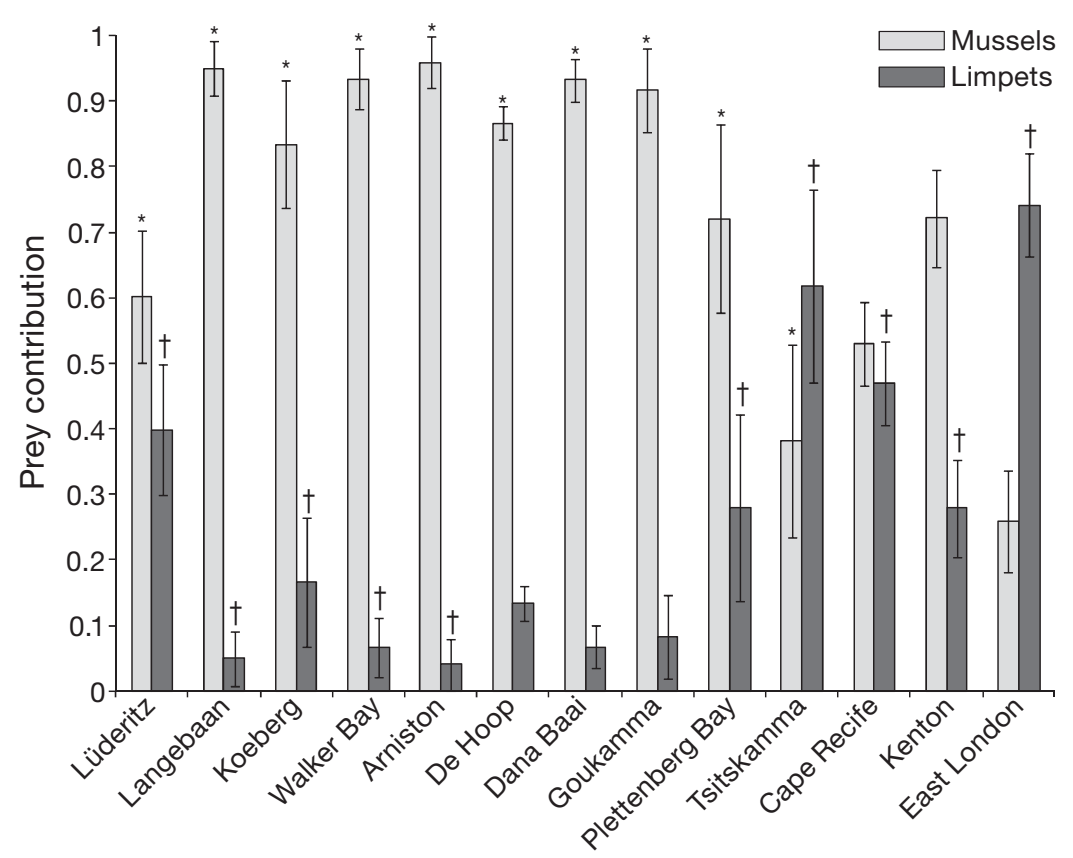

area, and a contrast was evident between the west/southwest coasts and the southeast coast (Fig. 5). ABOs relied almost exclusively on mussels between Langebaan (95.0\%) and Goukamma $(91.7 \%)$ while the contributions of mussels and limpets were more balanced in Namibia (60.1 and 39.9\%, respectively) and at the eastern sites, between Plettenberg Bay and Kenton $\left(\min _{\text {mussels }}=38.2 \pm 14.8 \%\right.$, max $_{\text {mussels }}=$ $72.1 \pm 7.4 \%$ ). In East London, $74.1 \%$ of the overall diet of ABOs was composed of limpets.

The presence/absence of limpets on feeding grounds (see Fig. 5) had no effect on the overall dietary composition of birds (ANOVA: $F_{1,11}=2.20, \mathrm{p}=0.17$ ). The presence of Mytilus galloprovincialis, however, had a significant effect expressed as an increase in the relative contribution of mussels to ABO diets (ANOVA: $F_{1,11}=5.54, \mathrm{p}=0.04$ ). Additionally there was no significant interaction between the effects of $M$. galloprovincialis and whether limpets were present (ANOVA: $F_{2,10}=3.27, \mathrm{p}=0.08$ ).

\section{DISCUSSION}

The $\delta^{13} \mathrm{C}$ and $\delta^{15} \mathrm{~N}$ signatures of ABOs in this study allowed us to discriminate between oystercatchers from different biogeographic locations and group them into 3 distinct clusters. Birds from the west coast were enriched in ${ }^{15} \mathrm{~N}$, birds from the southeast coast were en-

Fig. 5. Haematopus moquini. Contributions of mussels and limpets to the African black oystercatcher's diet along the coastline. Values are mean \pm SD estimated from Bayesian mixing models (SIAR). Blood isotope signatures of African black oystercatchers and potential sources used in the model are presented in Tables 1 \& 2. Results for mussel species and limpet species were pooled for each site in accordance with the Phillips et al. (2005) a posteriori aggregation. Trophic enrichment factors (see method for TEF estimations in 'Materials and methods') used were $+0.2 \pm 0.4 \%$ for $\delta^{13} \mathrm{C}$ and $+2.7 \pm 0.4 \%$ for $\delta^{15} \mathrm{~N}$. Symbols * and $\dagger$ indicate sites where Mytilus galloprovincialis and limpets, respectively, were present on the feeding grounds 
riched in ${ }^{13} \mathrm{C}$ and birds from the southwest coast had depleted $\delta^{13} \mathrm{C}$ ratios (see Fig. 4). This clear isotopic pattern in biogeography is similar to those found in previous studies conducted from lower trophic levels to top predators in the region (Hill et al. 2006, Hill \& McQuaid 2008, Jaquemet \& McQuaid 2008), where organisms from the Agulhas and Benguela systems could be segregated by their carbon and nitrogen signatures. Furthermore, differences in $\delta^{13} \mathrm{C}$ signatures of oystercatchers among sites reflected variations in the relative consumption of mussels and limpets associated with changes in prey community structure (Hockey \& van Erkom Schurink 1992, Bustamante \& Branch 1996).

\section{Oligotrophic versus productive systems}

Clear ${ }^{15} \mathrm{~N}$ enrichment was observed between the southeast and west coasts in oystercatchers and mussels, and to a lesser extent in limpets. This westward enrichment was previously described for rocky shore mussels and other benthic filter feeders on the South African coastline (Hill et al. 2006, Hill \& McQuaid 2008) and for Cape gannets Morus capensis on offshore islands (Jaquemet \& McQuaid 2008). Presumably the $\delta^{15} \mathrm{~N}$ gradient between organisms from the regions dominated by the Agulhas Current and the Benguela upwelling system mirrors the isotope shift described by Saino \& Hattori (1980) between waters that are oligotrophic (reliance on recycled nitrogen, i.e. ${ }^{15} \mathrm{~N}$ depleted) to those that are eutrophic (rich in nitrates, i.e. ${ }^{15} \mathrm{~N}$ enriched). Surprisingly, however, the southeast-west coast increase in $\delta^{15} \mathrm{~N}$ was disjointed and samples collected in Cape Recife, just outside Port Elizabeth, and Langebaan located within Saldanha Bay, displayed high nitrogen-isotope ratios compared with adjacent sampling sites. This may be the result of increased nitrogen-loading through anthropogenic inputs (Heaton 1986, Schaal et al. 2010) associated with urban, industrial and tourist activities in these areas. Another discrepancy was observed in Walker Bay where the limpet Scutellastra granularis displayed ${ }^{15} \mathrm{~N}$-depleted signatures. We do not have a clear explanation for this pattern other than possible local depletion in the $\delta^{15} \mathrm{~N}$ ratios of the benthic algae on which this limpet grazes. Overall local and large-scale patterns of nitrogen-isotope ratios in benthic invertebrates and oystercatchers confirm that large scale physical processes affecting patterns of primary productivity are transmitted up through the intertidal food web to a rocky shore predator.

Carbon signatures of $\mathrm{ABO}$ and their prey showed clear differences from biogeographic patterns of ${ }^{13} \mathrm{C}$ enrichment in SPM and mussels from the east coast to Cape Agulhas, which were suggested to mirror changes in the overall composition of nearshore SPM (phytoplankton versus macroalgae detritus; Hill et al. 2006, see also Bode et al. 2006). Our mussel data showed consistent $\delta^{13} \mathrm{C}$ ratios across the board of ca. $-15.7 \%$ ( \pm 0.5$)$ between Arniston and East London, with one exception (Tsitsikamma $=-14.2 \pm 0.2 \%$ ). This difference from previous studies probably reflects the type of local and interannual changes in coastal hydrography described by Hill et al. (2008). In contrast, the $\delta^{13} \mathrm{C}$ depletion in mussels, limpets and oystercatchers sampled off the Namibian coast conformed to expected biogeographic patterns (Hill et al. 2006) and thus appears to be consistent through time and visible at multiple levels of the intertidal food web. The mechanisms behind this depletion are not well understood and further isotopic investigations into nutrient dynamics and upwelling processes of the Benguela ecosystem are needed. With the exception of Lüderitz, the geographic variations of limpet $\delta^{13} \mathrm{C}$ ratios (Fig. 3a) appeared to be linked to the species pool rather than environmental conditions. For example, the territorial limpet Scutellastra longicosta displayed particularly ${ }^{13} \mathrm{C}$-enriched signatures, which confirmed its reliance on gardens of Ralfsia verrucosa (McQuaid \& Froneman 1993, Hill \& McQuaid 2008) and clearly departed from the $\delta^{13} \mathrm{C}$ displayed by other species. This obviously increased the mean $\delta^{13} \mathrm{C}$ values for limpets on the southwest and southeast coasts when $S$. longicosta was present (see Table 2). Some significant localized variations and large standard deviations in limpets (see Table 2) also suggested local and micro-scale variability, either in the composition of the benthic algae and/or the conditions (e.g. carbon source, light intensity, temperature) affecting photosynthesis and therefore isotopic fractionation of the benthic primary producers on which the limpets graze (Wong \& Sackett 1978, Burkhardt et al. 1999).

Large scale $\delta^{13} \mathrm{C}$ patterns at the base of marine food webs in relation to spatial variability of $\mathrm{CO}_{2}$ concentration, water temperature and growth rates of primary producers (Rau et al. 1982, Goericke \& Fry 1994) have been widely used to investigate animal migration patterns (see review in Hobson 1999) and foraging movements in marine predators (Burton \& Koch 1999, Quillfeldt et al. 2005). $\delta^{13} \mathrm{C}$ ratios can also be used to identify the ultimate sources of carbon for consumers when the ${ }^{13} \mathrm{C}$ signatures of food sources differ (Post 2002), and in the case of higher level predators, can help to determine the main component of the diet. This latter aspect was clearly shown in this study as the blood $\delta^{13} \mathrm{C}$ variations in $\mathrm{ABOs}$ did not correlate with the geographic variations displayed by either mussels or limpets, but instead oscillated between the contrasting ${ }^{13} \mathrm{C}$ signatures of the 2 main prey items. This confirms that although primary/secondary consumer ratios 
may reflect geographic differences in nutrient/primary productivity regimes, variations in the $\delta^{13} \mathrm{C}$ signatures of $\mathrm{ABO}$ are primarily due to the proportion of grazers and filter feeders in their diet across the sampling range.

\section{Effect of prey assemblages on the diet of African black oystercatchers}

The blood $\delta^{13} \mathrm{C}$ signatures of oystercatchers varied significantly along the coastline, ranging between ca. $-11.0 \%$ and $-17.0 \%$, with maximum $\delta^{13} \mathrm{C}$ values observed between Tsitsikamma and East London, and the lowest value on the southwest coast. Limpets were enriched in ${ }^{13} \mathrm{C}$ compared with mussels throughout the study area, which is an isotopic segregation typically observed between grazers and filter feeders (Post 2002, Schaal et al. 2008). In contrast, the ${ }^{15} \mathrm{~N}$ signatures of mussels and limpets were very similar at a local scale, with the exception of the west coast, and varied mostly in relation to changes in primary production processes associated with the Benguela and Agulhas ecosystems.

Broadly contrasting $\delta^{13} \mathrm{C}$ ratios and local differences in $\delta^{15} \mathrm{~N}$ ratios between prey allowed the application of the stable isotope mixing model SIAR to relate geographic variations in $\mathrm{ABO}$ isotope signatures to potential changes in the assimilation of mussels or limpets in their diet along the coastline. The SIAR model revealed a biogeographic pattern in the contribution of different prey to the diet of ABOs with the diet largely dominated by mussels on the west and southwest coasts of South Africa and a mixed diet of mussels and limpets in Namibia and on the southeast coast of South Africa. Finally, on the eastern boundary of the study area, limpets made up nearly $75 \%$ of the prey items assimilated by ABOs (Fig. 5). This shift in diet along the coastline indicates that $\mathrm{ABO}$ prey selection is influenced by prey availability, which reflects biogeographic trends in species composition and abundances along the coastline (Bustamante \& Branch 1996). The extremely high abundances of the invasive Mediterranean mussel on the west coast have a particularly clear effect on bird diets (see 'Results').

The west coast supports a higher intertidal invertebrate biomass than do the south and east coasts, reflecting the higher productivity of the Benguela upwelling system as opposed to the oligotrophic Agulhas Current. Following the arrival of the invasive Mediterranean mussel on the west coast in the 1980s (Grant \& Cherry 1985), the benthic biomass on rocky shores in this region became largely dominated by this species (Robinson et al. 2007). In Saldanha Bay, a change in the feeding habits of ABOs following the invasion by Mytilus galloprovincialis in the 1980s has been described for 3 offshore islands, based on direct observations or collections of emptied mollusc shells left by adults feeding their chicks (Hockey \& van Erkom Schurink 1992, Coleman \& Hockey 2008). ABOs had shifted from a mixed diet of mussels (the ribbed mussel Aulocomya ater and the black mussel Choromytilus meridionalis) and limpets (mainly Scutellastra granularis on these islands) before the invasion, to a diet dominated by M. galloprovincialis in the late 1980s and 1990s. Our results show an even more extreme scenario in Langebaan in 2009 (also situated in Saldanha Bay, but on the mainland), where M. galloprovincialis accounts for $95 \%$ of the prey versus $5 \%$ for the limpet $S$. argenvillei. In Walker Bay and Koeberg, similar preference for the invasive mussel was observed (Fig. 5) despite the presence of the limpets $S$. granularis or $S$. argenvillei previously favoured by ABOs (Hockey \& Underhill 1984). During the 1979-1980 breeding season in the Lüderitz region, Namibia, the diet of ABOs was almost exclusively composed of limpets (average, 96.8\%; Hockey \& Underhill 1984). M. galloprovincialis is now well established on the southern Namibian coast and dominates rocky shores in the Lüderitz region (B. Currie pers. comm.). Results from the present study show that mussels have become the predominant source of food for ABOs here; although, limpets still contribute significantly $(39.9 \pm 0.6 \%)$. Even though the diet of oystercatchers remains more balanced in Namibia than on the South African west coast, the increasing reliance on the Mediterranean mussel reflects a clear dietary shift in response to changes in prey availability. On the southwest coast, mussels also dominated the diet of ABOs (between 72 and 95\%), except at the eastern boundary of the region (only $40 \%$ ) in Tsitsikamma (see Fig. 5). This is not surprising as limpets were scarce or even absent from the oystercatchers' feeding grounds between De Hoop and Goukamma. The inverse proportions of filter feeders and grazers in the diet of ABOs between Plettenberg Bay (mussels = 72\%, limpets $=28 \%$ ) and Tsitsikamma (mussels $=38 \%$, limpets $=62 \%$ ) is surprising, however, considering that the 2 sites are separated by only $\sim 50 \mathrm{~km}$ (see Fig. 1). Bownes \& McQuaid (2006) investigated the potential for $M$. galloprovincialis to replace the indigenous mussel Perna perna on the south coast, in Plettenberg Bay and Tsitsikamma. They observed that mussel abundance was significantly lower in Tsitsikamma than in Plettenberg Bay, which forms a focal point of high M. galloprovincialis abundance along this coast (von der Meden et al. 2008), and mixing model outputs from our study support this finding. P. perna and M. galloprovincialis co-occurred at 6 sites, but were sometimes the only prey available. Based on empty shell and feeding area analysis, Kohler et al. (2009) reported ABOs actively selected the invasive mussel instead of 
the indigenous mussel to feed their chicks at Port Elizabeth, probably because $M$. galloprovincialis has weaker attachment strength than does $P$. perna (Zardi et al. 2007). Unfortunately, the lack of differences in $\delta^{13} \mathrm{C}$ and $\delta^{15} \mathrm{~N}$ signatures between these 2 mussel species prevented confirmation of this selective behaviour farther west where they often co-occur. This emphasizes the need to combine stable isotope analyses with more conventional techniques (e.g. feeding behaviour observations, collection of food remains) in the study of marine predators when possible.

The diet of ABOs on the southeast coast was characterized by a significant contribution of limpets; however, the brown mussel Perna perna was also well represented, specifically in Kenton (72\%). This is consistent with a previous study (Kohler et al. 2009), where $P$. perna represented between 84 and $97 \%$ of the relative prey abundance on 3 of the feeding grounds sampled in this area for the present study. Indeed mussel dominance on rocky shores is driven by wave exposure (Bustamante \& Branch 1996), which is strong in Kenton (McQuaid \& Lindsay 2007). Mytilus galloprovincialis remains scarce and site-specific on this part of the coastline (Bownes \& McQuaid 2006) and no invasive mussels $>16 \mathrm{~mm}$ (minimum shell size for consumption by ABOs, see Hockey \& Underhill 1984) were found on feeding grounds sampled at Cape Recife, Kenton or East London. Thus, as opposed to the southwest and west coasts sites, breeding sites sampled on the southeast coast have so far effectively been unaffected by the M. galloprovincialis invasion. Thus, the feeding behaviour of ABOs on the southeast coast can also be regarded as 'unaltered', but will be mediated by extrinsic factors such as wave action and sex-specific or individual specialization, as documented for other oystercatcher species (Baker 1974, Goss-Custard \& Sutherland 1984, Lauro \& Nol 1995).

\section{Seasonal variation in the trophic ecology of the African black oystercatcher}

Variations in stable isotope ratios of blood and feathers displayed very strong correlations along the coastline for both $\delta^{13} \mathrm{C}$ and $\delta^{15} \mathrm{~N}$. Adult ABOs are known to be territorial year-round (Hockey 1996), which suggests an overall seasonal stability in the environmental conditions that influence rocky shore food webs along the coastline and a consistency in the feeding behaviour of adults throughout the year. However, some local discrepancies were observed between the blood and feather ratios. In East London for example, the blood-feather $\delta^{15} \mathrm{~N}$ discrimination factor was $+0.6 \%$ (as opposed to $+1.6 \pm 0.4 \%$ for adults throughout the study area and $+1.2 \pm 0.3 \%$ for large chicks). This indi- cates either a seasonal shift in feeding behaviour, or that outside the breeding season, ABOs from East London feed in areas that have lower $\delta^{15} \mathrm{~N}$ ratios at the base of the food web than those found in their breeding site. Another clear blood-feather shift was in Dana Baai $(+2.6 \%)$, which indicated that adults there seemed to feed in a wintering habitat that has a higher basal $\delta^{15} \mathrm{~N}$ than does the breeding habitat.

Climate variations between seasons are mild in the study region compared with the northern hemisphere, where oystercatchers have to endure harsh winters and often migrate southwards (Goss-Custard et al. 1996). Consequently, like the other southern hemisphere oystercatcher species, breeding ABOs, especially those birds that breed on offshore islands on the west coast of South Africa, do not migrate after reproduction but remain territorial year-round (Hockey 1996, Tjørve \& Underhill 2006, Coleman \& Hockey 2008). However, colour-ringed birds have been resighted in flocks over $10 \mathrm{~km}$ east from their breeding site during the nonbreeding season in the East London region (SAFRING), while in Kenton, colour-ringed pairs are rarely spotted on their breeding site outside the breeding season (S. A. Kohler pers. obs.). Similarly in Goukamma and Plettenberg Bay, breeding pairs do not stay on their breeding site; instead, large flocks of birds gather around river mouths and on beaches during winter (J. Huisamen \& C. D. McQuaid pers. obs.). Therefore, it seems that on the southwest and southeast coasts, adults move around substantially outside the breeding season. This again reflects a contrast between the west coast and the rest of the breeding range for the $\mathrm{ABO}$. One potential explanation may be that breeders are not bound to their feeding territory and confines during winter and may choose to move to more advantageous feeding areas. Conversely, on the west coast, feeding territories may be profitable for year-round occupation, because of high food biomass (Hockey \& van Erkom Schurink 1992, Bustamante \& Branch 1996). Further investigation of the wintering movement strategies of ABOs would require complementary techniques such as radio telemetry (Warnock \& Takekawa 2003, Wilson et al. 2009)

\section{CONCLUSIONS}

Overall, we show that carbon and nitrogen stable isotope ratios in a rocky shore avian predator, the African black oystercatcher, reflected the integration of largescale patterns of both primary productivity and prey assemblages. This indicates that the influence of major large-scale current systems penetrates to the top of the food web, but also that local-scale effects embedded within this framework can be important. The $\delta^{15} \mathrm{~N}$ vari- 
ations of the tissues of ABOs were indicative of changes in intertidal nutrient quality in relation to major oceanic influences along the southern African coastline and local anthropogenic perturbations. $\delta^{13} \mathrm{C}$ ratios and stable isotope mixing models revealed geographic changes in the main diet of ABOs that were strongly influenced by the presence of the invasive mussel, Mytilus galloprovincialis. ABOs demonstrated plasticity in their trophic ecology in connection with biogeographic provinces, changes in prey communities and seasonality. In the context of global changes and overexploitation of marine resources, this could help them face future changes in their trophic environment.

Acknowledgements. The authors thank CapeNature, SANParks and Koeberg Nature Reserve for granting access to conservation areas, and for human and logistic support. They are very grateful to B. Bonnevie, B. Dubillot, J. Kolasinski, P. Martin, P. Pinet, A. Valery, C. Vernon and the Lakes Bird Club for their assistance in the field. V. Denis and G. Schaal made useful suggestions during the writing of early drafts. The manuscript benefitted from the constructive comments of 3 anonymous reviewers. Isotope samples were analyzed by I. Newton at the Stable Light Isotope Laboratory, University of Cape Town, under the supervision of J. Lanham. This research was financially supported by a MARG I from WIOMSA, a research grant from Région Réunion, Rhodes University, and was based upon research supported by the South African Research Chairs Initiative of the Department of Science and Technology and the National Research Foundation. S.A.K. was funded by a PhD grant awarded by the French Ministry of Higher Education and Research via the University of La Réunion.

\section{LITERATURE CITED}

Atkinson PW, Baker AJ, Bevan RM, Clark NA and others (2005) Unravelling the migration and moult strategies of a long-distance migrant using stable isotopes: red knot (Calidris canutus) movements in the Americas. Ibis 147: 738-749

Baker AJ (1974) Prey specific feeding methods of New Zealand oystercatchers. Notornis 21:219-234

> Bearhop S, Waldron S, Votier S, Furness R (2002) Factors that influence assimilation rates and fractionation of nitrogen and carbon stable isotopes in avian blood and feathers. Physiol Biochem Zool 75:451-458

Bode A, Alvarez-Ossorio MT, Varela M (2006) Phytoplankton and macrophyte contributions to littoral food webs in the Galician upwelling estimated from stable isotopes. Mar Ecol Prog Ser 318:89-102

Bownes SJ, McQuaid CD (2006) Will the invasive mussel Mytilus galloprovincialis Lamarck replace the indigenous Perna perna L. on the south coast of South Africa? J Exp Mar Biol Ecol 338:140-151

Branch GM, Steffani CN (2004) Can we predict the effects of alien species? A case-history of the invasion of South Africa by Mytilus galloprovincialis (Lamarck). J Exp Mar Biol Ecol 300:189-215

> Brown M, Hockey PAR (2007) The status and distribution of African black oystercatchers Haematopus moquini in
Kwazulu-Natal, South Africa. Ostrich 78:93-96

Burkhardt S, Riebesell U, Zondervan I (1999) Stable carbon isotope fractionation by marine phytoplankton in response to daylength, growth rate and $\mathrm{CO}_{2}$ availability. Mar Ecol Prog Ser 184:31-41

Burton RK, Koch PL (1999) Isotopic tracking of foraging and long-distance migration in northeastern Pacific pinnipeds. Oecologia 119:578-585

> Bustamante RH, Branch GM (1996) Large scale patterns and trophic structure of southern African rocky shores: the roles of geographic variation and wave exposure. J Biogeogr 23:339-351

Cherel Y, Hobson KA (2007) Geographical variation in carbon stable isotope signatures of marine predators: a tool to investigate their foraging areas in the Southern Ocean. Mar Ecol Prog Ser 329:281-287

Cherel Y, Hobson KA, Hassani S (2005) Isotopic discrimination between food and blood and feathers of captive penguins: implications for dietary studies in the wild. Physiol Biochem Zool 78:106-115

Coleman RA, Hockey PAR (2008) Effects of an alien invertebrate species and wave action on prey selection by African black oystercatchers (Haematopus moquini). Austral Ecol 33:232-240

> Dalerum F, Angerbjörn A (2005) Resolving temporal variation in vertebrate diets using naturally occurring stable isotopes. Oecologia 144:647-658

> Dare PJ, Mercer AJ (1974) The timing of wingmoult in the oystercatcher Haematopus ostralegus in Wales. Ibis 116: 211-214

- Emanuel BP, Bustamante RH, Branch GM, Eekhout S, Odendaal FJ (1992) A zoogeographic and functional approach to the selection of marine reserves on the west coast of South Africa. S Afr J Mar Sci 12:341-354

Erlandsson J, Pal P, McQuaid CD (2006) Re-colonisation rate differs between co-existing indigenous and invasive intertidal mussels following major disturbance. Mar Ecol Prog Ser 320:169-176

> Evans Ogden LJ, Hobson KA, Lank DB (2004) Blood isotopic $\left(\delta^{13} \mathrm{C}\right.$ and $\left.\delta^{15} \mathrm{~N}\right)$ turnover and diet-tissue fractionation factors in captive dunlin (Calidris alpinia pacifica). Auk 121: 170-177

France RL (1995) Carbon-13 enrichment in benthic compared to planktonic algae: foodweb implications. Mar Ecol Prog Ser 124:307-312

Fry B, Sherr EB (1984) $\delta^{13} \mathrm{C}$ measurements as indicators of carbon flow in marine and freshwater ecosystems. Contrib Mar Sci 27:13-47

Goericke R, Fry B (1994) Variations of marine plankton $\delta^{13} \mathrm{C}$ with latitude, temperature, and dissolved $\mathrm{CO}_{2}$ in the world ocean. Global Biogeochem Cycles 8:85-90

> Gorokhova E, Hansson S (1999) An experimental study on variations in stable carbon and nitrogen isotope fractionation during growth of Mysis mixta and Neomysis integer. Can J Fish Aquat Sci 56:2203-2210

Goss-Custard JD, Le V dit Durell SEA, Goater CP, Hulscher JB, Lambeck RHD, Meininger PL, Urfi J (1996) How Oystercatchers survive the winter. In: Goss-Custard JD (ed) The Oystercatcher: from individuals to populations. Oxford Ornithol Ser 7, Oxford University Press, Oxford, p 133-155

Goss-Custard JD, Sutherland WJ (1984) Feeding specializations in oystercatchers Haematopus ostralegus. Anim Behav 32:299-301

> Grant WS, Cherry MI (1985) Mytilus galloprovincialis Lmk. in southern Africa. J Exp Mar Biol Ecol 90:179-191

Heaton THE (1986) Isotopic studies of nitrogen pollution in 
the hydrosphere and atmosphere: a review. Chem Geol 59:87-102

Hill JM, McQuaid CD (2008) $\delta^{13} \mathrm{C}$ and $\delta^{15} \mathrm{~N}$ biogeographic trends in rocky intertidal communities along the coast of South Africa: evidence of strong environmental signatures. Estuar Coast Shelf Sci 80:261-268

Hill J, McQuaid C (2009) Effects of food quality on tissuespecific isotope ratios in the mussel Perna perna. Hydrobiologia 635:81-94

Hill JM, McQuaid CD, Kaehler S (2006) Biogeographic and nearshore-offshore trends in isotope ratios of intertidal mussels and their food sources around the coast of southern Africa. Mar Ecol Prog Ser 318:63-73

> Hill JM, McQuaid CD, Kaehler S (2008) Temporal and spatial variability in stable isotope ratios of SPM link to local hydrography and longer term SPM averages suggest heavy dependence of mussels on nearshore production. Mar Biol 154:899-909

Hobson KA (1999) Tracing origins and migration of wildlife using stable isotopes: a review. Oecologia 120:314-326

> Hobson KA, Clark RG (1992a) Assessing avian diets using stable isotopes I: turnover of ${ }^{13} \mathrm{C}$ in tissues. Condor 94:181-188

> Hobson KA, Clark RG (1992b) Assessing avian diets using stable isotopes II: factors influencing diet-tissue fractionation. Condor 94:189-197

Hockey PAR (1983) The distribution, population size, movements and conservation of the African black oystercatcher Haematopus moquini. Biol Conserv 25:233-262

Hockey PAR (1996) Haematopus ostralegus in perspective: comparisons with other oystercatchers. In: Goss-Custard JD (ed) The Oystercatcher: from individuals to populations. Oxford University Press, Oxford, p 251-285

Hockey PAR (1997) African black oystercatcher: between the tides. In: Africa birds and birding. Africa Geographic, Cape Town, p 28-34

Hockey PAR, Underhill LG (1984) Diet of the African black oystercatcher Haematopus moquini on rocky shores: spatial, temporal and sex related variation. S Afr J Zool 19: $1-11$

Hockey PAR, van Erkom Schurink C (1992) The invasive biology of the mussel Mytilus galloprovincialis on the southern African coast. Trans R Soc S Afr 48:123-139

Hockey PAR, Dean WRJ, Ryan PJ (2005) Roberts birds of southern Africa. Trustees of the John Voelcker Bird Book Fund, Cape Town

- Hulscher JB (1977) The progress of wing-moult of Oystercatchers Haematopus ostralegus at Drachten, Netherlands. Ibis 119:507-512

- Jaeger A, Blanchard P, Richard P, Cherel Y (2009) Using carbon and nitrogen isotopic values of body feathers to infer inter- and intra-individual variations of seabird feeding ecology during moult. Mar Biol 156:1233-1240

> Jaquemet S, McQuaid CD (2008) Stable isotope ratios in Cape gannets around the southern coasts of Africa reveal penetration of biogeographic patterns in oceanic signatures. Estuar Coast Shelf Sci 80:374-380

Klaassen M, Lindstrom A, Meltofte H, Piersma T (2001) Arctic waders are not capital breeders. Nature 413:794

Kohler S, Bonnevie B, McQuaid C, Jaquemet S (2009) Foraging ecology of an endemic shorebird, the African Black Oystercatcher (Haematopus moquini) on the south-east coast of South Africa. Estuar Coast Shelf Sci 84:361-366

Lauro B, Nol E (1995) Feeding behavior, prey selection, and bill size of Pied and Sooty Oystercatchers in Australia. Wilson Bull 107:629-640

> Lefebvre S, Harma C, Blin JL (2009) Trophic typology of coastal ecosystems based on $\delta^{13} \mathrm{C}$ and $\delta^{15} \mathrm{~N}$ ratios in an opportunis- tic suspension feeder. Mar Ecol Prog Ser 390:27-37

Lutjeharms JRE (2004) The coastal ocean of south-eastern Africa. In: Robinson AR, Brink KH (eds) The sea, Vol 14. Harvard University Press, Cambridge, MA, p 781-832

McQuaid CD, Froneman PW (1993) Mutualism between the territorial intertidal limpet Patella longicosta and the crustose alga Ralfsia verrucosa. Oecologia 96:128-133

McQuaid C, Lindsay T (2007) Wave exposure effects on population structure and recruitment in the mussel Perna perna suggest regulation primarily through availability of recruits and food, not space. Mar Biol 151:2123-2131

- McQuaid CD, Phillips TE (2000) Limited wind-driven dispersal of intertidal mussel larvae: in situ evidence from the plankton and the spread of the invasive species Mytilus galloprovincialis in South Africa. Mar Ecol Prog Ser 201: 211-220

Menge BA, Lubchenco J, Bracken MES, Chan F and others (2003) Coastal oceanography sets the pace of rocky intertidal community dynamics. Proc Natl Acad Sci USA 100: 12229-12234

Mizutani H, Fukuda M, Kabaya Y, Wada E (1990) Carbon isotope ratio of feathers reveals feeding behavior of Cormorants. Auk 107:400-403

Parnell AC, Inger R, Bearhop S, Jackson AL (2010) Source partitioning using stable isotopes: coping with too much variation. PLoS ONE 5:e9672

Phillips DL, Newsome SD, Gregg JW (2005) Combining sources in stable isotope mixing models: alternative methods. Oecologia 144:520-527

Ponsard S, Averbuch P (1999) Should growing and adult animals fed on the same diet show different $\delta^{15} \mathrm{~N}$ values? Rapid Commun Mass Spectrom 13:1305-1310

Post DM (2002) Using stable isotopes to estimate trophic position: models, methods, and assumptions. Ecology 83: 703-718

Quillfeldt P, McGill RAR, Furness RW (2005) Diet and foraging areas of Southern Ocean seabirds and their prey inferred from stable isotopes: review and case study of Wilson's storm-petrel. Mar Ecol Prog Ser 295:295-304

R Development Core Team (2008) R: a language and environment for statistical computing. R Foundation for Statistical Computing, Vienna

Rau GH, Sweeney RE, Kaplan IR (1982) Plankton ${ }^{13} \mathrm{C}:{ }^{12} \mathrm{C}$ ratio changes with latitude: differences between northern and southern oceans. Deep-Sea Res Part A 29:1035-1039

Robinson TB, Griffiths CL, McQuaid CD, Rius M (2005) Marine alien species of South Africa - status and impacts. Afr J Mar Sci 27:297-306

Robinson TB, Branch GM, Griffiths CL, Govender A, Hockey PAR (2007) Changes in South African rocky intertidal invertebrate community structure associated with the invasion of the mussel Mytilus galloprovincialis. Mar Ecol Prog Ser 340:163-171

> Saino T, Hattori A (1980) ${ }^{15} \mathrm{~N}$ natural abundance in oceanic suspended particular matter. Nature 283:752-754

> Schaal G, Riera P, Leroux C (2008) Trophic coupling between two adjacent benthic food webs within a man-made intertidal area: a stable isotopes evidence. Estuar Coast Shelf Sci 77:523-534

Schaal G, Riera P, Leroux C, Grall J (2010) A seasonal stable isotope survey of the food web associated to a peri-urban rocky shore. Mar Biol 157:283-294

Shannon LV (1985) The Benguela ecosystem. Part 1: evolution of the Benguela physical features and processes. Oceanogr Mar Biol Annu Rev 23:105-182

Steffani CN, Branch GM (2003) Spatial comparisons of populations of an indigenous limpet Scutellastra argenvillei 
and an alien mussel Mytilus galloprovincialis along a gradient of wave energy. Afr J Mar Sci 25:115-212

Tieszen LL, Boutton TW, Tesdahl KG, Slade NA (1983) Fractionation and turnover of stable carbon isotopes in animal tissues: implications for $\delta^{13} \mathrm{C}$ analysis of diet. Oecologia 57: 32-37

Tjørve KMC, Underhill LG (2006) Population increase of African Black Oystercatchers Haematopus moquini on Robben Island, South Africa. Ostrich 77:229-232

Vanderklift M, Ponsard S (2003) Sources of variation in consumer-diet $\delta^{15} \mathrm{~N}$ enrichment: a meta-analysis. Oecologia 136:169-182

> Vernon CJ (2004) Status and abundance of the African black oystercatcher (Haematopus moquini) at the eastern limit of its breeding range. Ostrich 75:243-249

- Von der Meden CEO, Porri F, Erlandsson J, McQuaid CD (2008) Coastline topography affects the distribution of indigenous and invasive mussels. Mar Ecol Prog Ser 372: 135-145

Editorial responsibility: Michael Castellini,

Fairbanks, Alaska, USA
Warnock N, Takekawa JY (2003) Use of radio telemetry in studies of shorebirds' past contributions and future directions. Wader Study Group Bull 100:138-150

Williams AJ, Wardi VL, Underhill LG (2004) Waders respond quickly and positively to the banning of off-road vehicles from beaches in South Africa. Wader Study Group Bull 104:79-81

Wilson LJ, McSorley CA, Gray CM, Dean BJ, Dunn TE, Webb A, Reid JB (2009) Radio-telemetry as a tool to define protected areas for seabirds in the marine environment. Biol Conserv 142:1808-1817

Wong WW, Sackett WM (1978) Fractionation of stable carbon isotopes by marine phytoplankton. Geochim Cosmochim Acta 42:1809-1815

Zardi GI, McQuaid CD, Nicastro KR (2007) Balancing survival and reproduction: seasonality of wave action, attachment strength and reproductive output in indigenous Perna perna and invasive Mytilus galloprovincialis mussels. Mar Ecol Prog Ser 334:155-163

Submitted: December 20, 2010; Accepted: May 18, 2011

Proofs received from author(s): August 5, 2011 